\title{
A Century of Global Equity Market Correlations
}

\author{
By Dennis P. Quinn and Hans-Joachim Voth*
}

Stock markets around the globe often move in lockstep. The US market's direction in particular can add or subtract billions in value from stocks in other countries in a single day (Cheol Eun and Sangdal Shim 1989). Between many country indices, correlations are now relatively high ( 0.8 or above). Yet only a few decades ago, it was widely noted that correlations between stock markets were low (Herbert Grubel 1968; Haim Levy and Marshall Sarnat 1970). That correlations are not constant over time has been highlighted, inter alia, by William Goetzmann, Lingfen Li, and Geert Rouwenhoorst (2005). Higher correlations spell lower diversification benefits. If markets fluctuate in parallel, the advantages of moving money into overseas markets will be much smaller than previously thought - the "home bias" puzzle may be smaller than advertised.

In this paper, we use a unique long-run dataset of regulatory constraints on capital account openness to explain stock market correlations. Since stock returns themselves are highly volatile, any examination of what drives correlations needs to focus on long runs of data. This is particularly true since some of the short-term changes in co-movements appear to reverse themselves (Delroy Hunter 2005). We argue that changes in the co-movement of indices have not been random. Rather, they are mainly driven by greater freedom to move funds from one country to another. In related work, Geert Bekaert and Campbell Harvey (2000) show that equity correlations increase after liberalization of capital markets, using a number of case studies from emerging countries. We examine this pattern systematically for the last century, and find it to be most pronounced in the recent past. We compare the importance of capital account

\footnotetext{
* Quinn: McDonough School of Business, Georgetown University, Washington, DC 20057 USA (e-mail: quinnd@ georgetown.edu); Voth: DEE-UPF, c/Ramon Trias Fargas 25-27, Barcelona 08005, Spain (e-mail: jvoth@crei.cat). We thank Barry Eichengreen and Alan M. Taylor for helpful comments.
}

openness with one main alternative explanation, the growing synchronization of economic fundamentals. We conclude that greater openness has been the single most important cause of growing correlations during the last quarter of a century, though increasingly correlated economic fundamentals also matter. In the conclusion, we offer some thoughts on why the effects of greater openness appear to be so much stronger today than they were during the last era of globalization before 1914.

\section{Data}

Freedom to move capital from one country to another was commonplace a century ago. Maurice Obstfeld and Alan M. Taylor (2003) argue that nineteenth-century capital markets were at least as globalized as markets today. John Maynard Keynes (1920), in describing the delights of life before 1914, highlighted the ease with which funds were moved around the globe:
"The inhabitant of London could order by telephone, sipping his morning tea in bed, the various products of the whole earth... He could ... by the same means adventure his wealth in ... new enterprises of any quarter of the world, and share, without exertion or even trouble, in their prospective fruits...."

World War I saw heavy restrictions placed on the movement of funds. While the interwar period saw liberalization, it was only beginning to approach prewar levels of capital account openness before the twin shocks of the Great Depression and World War II shut down capital flows. The Bretton Woods system initially envisaged no role for free flows across borders. Keynes argued that the experience of the World Economic Crisis in the early 1930s had made it clear that while travel and trade should be free, capital transfers should be permanently restricted. The postwar period consequently saw a very slow and gradual return to current and capital account openness. Problems in ensuring 
Table 1-Capital Account Openness over the Last Century

\begin{tabular}{|c|c|c|c|c|}
\hline Period & Mean & $N$ & Minimum & Maximum \\
\hline 1890 & 96 & 114 & 50 & 100 \\
\hline 1894 & 100 & 114 & 100 & 100 \\
\hline 1898 & 100 & 114 & 100 & 100 \\
\hline 1902 & 100 & 114 & 100 & 100 \\
\hline 1906 & 100 & 114 & 100 & 100 \\
\hline 1910 & 100 & 114 & 100 & 100 \\
\hline 1914 & 93 & 114 & 75 & 100 \\
\hline 1918 & 66 & 120 & 42 & 94 \\
\hline 1922 & 57 & 120 & 19 & 90.5 \\
\hline 1926 & 85 & 120 & 19 & 100 \\
\hline 1930 & 70 & 120 & 15.5 & 100 \\
\hline 1934 & 56 & 120 & 0 & 90.5 \\
\hline 1938 & 50 & 120 & 0 & 87.5 \\
\hline 1942 & NA & NA & NA & NA \\
\hline 1946 & 25 & 105 & 0 & 100 \\
\hline 1950 & 45 & 120 & 3 & 100 \\
\hline 1954 & 57 & 120 & 11 & 100 \\
\hline 1958 & 65 & 120 & 22 & 100 \\
\hline 1962 & 67 & 120 & 25.5 & 100 \\
\hline 1966 & 66 & 120 & 31.5 & 100 \\
\hline 1970 & 67 & 120 & 38 & 98.5 \\
\hline 1974 & 68 & 120 & 38 & 100 \\
\hline 1978 & 72 & 120 & 48.5 & 98.5 \\
\hline 1982 & 77 & 120 & 53 & 100 \\
\hline 1986 & 85 & 120 & 64 & 100 \\
\hline 1990 & 93 & 120 & 75 & 100 \\
\hline 1994 & 95 & 120 & 75 & 100 \\
\hline 1998 & 97 & 120 & 81.5 & 100 \\
\hline Total & 76 & 3,183 & 0 & 100 \\
\hline
\end{tabular}

Notes: See text for sources. The countries represented are Australia, Belgium, Canada, Denmark, Finland, France, Germany, Italy, the Netherlands, New Zealand, Norway, Spain, Sweden, Switzerland, the United Kingdom, and the United States. Zero represents a closed economy, 100 represents a completely open economy. $N$ is number of country pairs.

an adequate supply of dollars in war-ravaged Europe added an extra note of caution (Barry Eichengreen 2006). While some countries like the United States and Germany had dismantled many controls by the early 1960 s, others such as the United Kingdom and Japan continued with massive interventions. Even after the collapse of the Bretton Woods system, many countries maintained various restrictions. The United Kingdom did not eliminate remaining capital controls until after the election of Margaret Thatcher in 1979. On the European continent, it took until the run-up to the European Monetary Union (EMU) to see the elimination of many restrictions that had stayed in place.

Capturing the history of capital account openness in a single indicator is not straightforward. For the recent past, codings based on the IMF's Annual Report on Exchange Restrictions have become widely accepted. ${ }^{1}$ We extend the existing series back to the late nineteenth century, using the standard coding scheme underlying the socalled Quinn-Toyoda measure of openness for a set of 16 developed countries. (See Quinn (1997, 2003) for descriptions.) Our unit of observation is the average openness in each country pair. In our dataset, openness ranges from a minimum of 0 to a maximum of 100 , with an average of 76. There is marked variation in the variable, as indicated by a standard deviation of 23 . The late nineteenth century has nearly completely open markets, as does the early twenty-first century (Table 1).

We combine these data with stock return correlations over the last century. We use the correlations of returns in nonoverlapping four-year

\footnotetext{
${ }^{1}$ See Eichengreen and Michael Bordo (1997).
} 


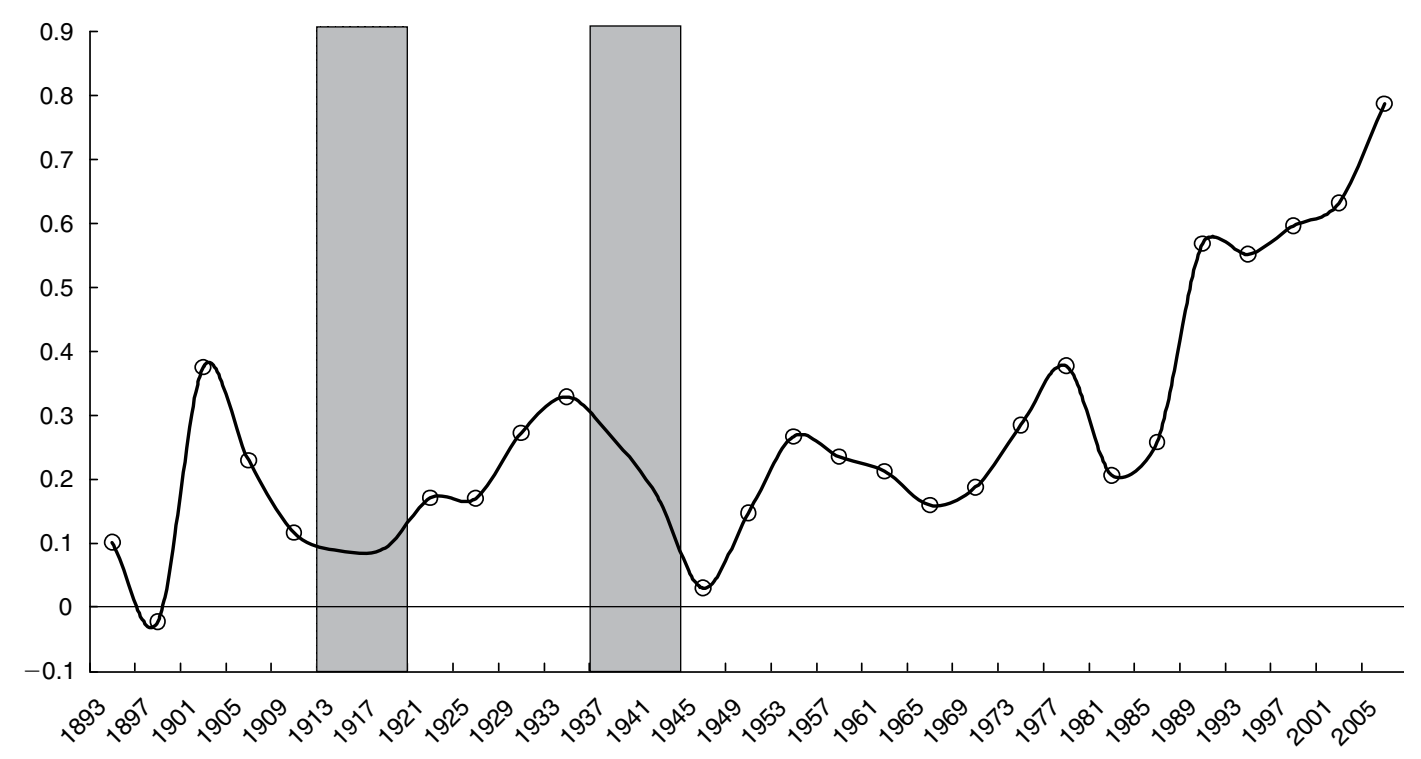

Figure 1: Stock Market Correlations over the Long Run

(Shaded areas indicate observations reflecting stock returns affected by the two world wars)

periods in 120 country pairs. Returns are calculated as log difference of monthly index values for main country indices such as the CDAX for Germany or the long-run equivalent of the S\&P 500 . As in other recent work on long-run return patterns (Eichengreen and Hui Tong 2003), we use data from the Global Financial Database (GFD) (2006). Where superior national sources exist — such as in the case of Germany — we use these instead. ${ }^{2}$

Figure 1 shows the variable that we are seeking to explain - the average of the correlation coefficients in our dyads. The early twentiethcentury shows a high in correlations of 0.4 , and a downturn even before World War I. The interwar period returns to this level of co-movement immediately before the onset of the Great Depression. The postwar period initially shows very low correlations. The early twentieth-century high is surpassed only in the mid-1980s. From the early 1990s, stock market correlations are at record levels, with each period showing covariances higher than the last one.

\footnotetext{
${ }^{2}$ Details available from the authors upon request.
}

\section{Data Analysis}

We find strong evidence that country pairs that are more open to capital flows also show greater co-movement of their stock markets. Both time series and cross-sectional evidence indicate a sizeable impact of capital account openness.

Regressions take the form

$$
\rho_{i, t}=a_{i}+\beta Q_{i, t}+\gamma \boldsymbol{X}_{i, t}^{\prime}+\varepsilon,
$$

where $\rho$ is the correlation coefficient of main stock market indices in country pair $i$ at time $t, a$ is the intercept, $Q$ is the Quinn-Toyoda measure of openness introduced earlier, and $\boldsymbol{X}$ is a set of control variables. Table 2 shows the basic results. We find a large and highly significant coefficient in our pooled sample. On average, countries that raised their openness from the twenty-fifth to the seventy-fifth percentile of the distribution saw an increase in the correlation of their stock markets by 0.2 , equivalent to a rise of 59 percent relative to the sample mean in our dataset $(0.32)$. Controlling for unobserved effects by adding time and country pair dummies improves the fit of our regressions. It also lowers the coefficient in our panel regressions. When both are used, 
Table 2-Effect of Capital Account Openness on Stock Market Correlations

\begin{tabular}{lcc}
\hline \hline & & $\begin{array}{c}\text { 3. Impact of raising Q } \\
\text { from 25th to } 75 \text { th } \\
\text { percentile }\end{array}$ \\
\hline 1. Specification & 2. Coefficient on Q & $0.19(+59$ percent $)$ \\
$\quad$ No fixed effects & $0.59(27.76)$ & $0.18(+54$ percent $)$ \\
Pair dummy & $0.57(25.90)$ & $0.05(+14$ percent $)$ \\
Pair + time dummies & $0.15(4.98)$ & $0.04(+13$ percent $)$ \\
$\quad$ Macro controls + & $0.14(4.89)$ & \\
$\quad$ pair + time dummies & & $0.37(+112$ percent $)$ \\
IV fixed effects & $1.18(17.06)$ & $0.37(+113$ percent $)$ \\
Pair dummy & $1.19(19.49)$ & $0.33(+101$ percent $)$ \\
Pair and time dummies & $1.06(2.29)$ & $0.32(+97$ percent $)$ \\
$\quad$ Macro controls + & $1.02(2.09)$ & \\
$\quad$ pair + time dummies & & \\
\hline
\end{tabular}

Notes: Q is the Quinn-Toyoda measure of capital account openness. The macro controls are interest rate correlation, GDP growth rate correlation, and bilateral trade volume. The $t$-statistic is in parentheses in column 2. The effect in parentheses in column 3 is calculated relative to the sample mean, which is 0.33 . The sample in all models contains 2,073 observations. The instrument for Q is EMU membership from 1994 onward. All estimation is for the period 1890 to 2001 .

we obtain a coefficient that is less than a third the size in the naïve specification. Nonetheless, the impact of openness remains large and statistically significant. Going from the twenty-fifth to the seventy-fifth percentile of openness now adds 0.05 to correlations. In related work, we also find an effect of the difference in capital account openness between countries, even after holding constant average openness in each dyad (Quinn and Voth 2007). Even if we assume that all time series variation is not useful for our purposes, leaving only cross-sectional variation to identify the effect of openness, the connection appears large and tightly estimated.

If multinational firms (MNFs) provide an effective means of international diversification, as some authors have argued (Tamir Agmon and Donald Lessard 1977), our results represent a lower bound of the true effect of cross-border capital flows on covariances. True liberalization would have risen less sharply than our indicators. If prior to the repeal of controls, some capital flows took the form of FDI, and comovements increased because the MNFs listed in one country do business in another, our estimation approach will understate the true effect of liberalization. Subsequent work by Randall Morck and Bernard Yeung (1991) also suggested that investors do not value MNFs as an alternative way to diversify their portfolios.
Are the effects in Table 2 causal? We want to take into account the possibility that real economic variables might have become more synchronized, causing greater co-movement of stock market indices. Controlling for all relevant fundamentals is an impossible task. We use the variables that are available consistently over the period of our study. Our macroeconomic controls are the correlation of GDP growth rates, interest rates, and bilateral trade flows. All these variables have the predicted sign. Adding the macro controls has a negligible influence on the size and significance of the openness variable.

An additional concern is that convergence in macroeconomic indicators may by itself raise the likelihood of liberalization. We attempt to address the issue through IV estimation. The EMU led to a sharp change in regime for European countries that retained some controls into the 1990s, such as Italy, Spain, and France. We use EMU membership as an instrument for capital account openness in the final four lines in Table 2. It takes the value one for members between 1994 and 1999, when decisions on the final set of countries joining EMU were made. ${ }^{3}$ The idea is to capture a change in

\footnotetext{
${ }^{3}$ We also experimented with a specification that set the variable to one for all member states from 1992 onward, or from 1996. The results are largely unchanged.
} 
openness imposed on countries as a condition for EMU membership, and one they would not have taken anyway as a result of growing correlations of fundamentals. The exclusion restriction that has to be valid for the IV exercise to be useful is that stock market correlations during the run-up to monetary union will not be influenced by future EMU membership, other than through greater openness. This seems plausible. However, if anticipation effects led to growing synchronization in the stock markets of future EMU members during the 1994-1999 period, our IV strategy would be invalid.

The IV results in general show lower statistical significance-as expected-but larger coefficients. This may seem surprising. Two factors may be at work. First, it is possible that using the EMU dummy solves a measurement problem in our openness index. We do not know with certainty which elements in the capital account openness measure are relevant for correlations. Also, an increase by, say, ten points on the Quinn-Toyoda scale in one country may be driven by changes relevant to equity purchases and sales; in another, the restrictions repealed may have little to do with portfolio flows (relating, say, to FDI but not to portfolio transactions). Since EMU membership often led to a cancelling of rules that had shut national capital markets to portfolio flows, the instrument may capture the more relevant part of overall variation. A second interpretation is that EMU itself boosted stock market synchronization, even controlling for fundamentals, since market participants expected future fundamentals to be moving in lockstep. In the latter case, EMU would have influenced correlations in a way that is unrelated to capital account openness, and our IV strategy would be invalid. Since fundamentals have not converged markedly after EMU, we are not convinced that the big leap in intraEuropean stock market correlations in the 1990s should be attributed to anticipation effects of an economic development that never took place.

\section{Conclusions}

Over the last century, capital account liberalizations have been accompanied by higher correlations of national stock markets with those abroad. Also, open countries have maintained higher correlation levels than closed ones. If our argument that capital account openness itself raises covariances is correct, it implies that diversification benefits in the future cannot be as high as many scholars writing in the 1960s predicted. Rather, as more and more countries open up to outside capital, the benefits from diversification are likely to decline. The "home bias puzzle" will be commensurately smaller. It is still possible that investors who are among the first to put their money into newly open markets can benefit from uncorrelated returns for a while. Further, high returns appear to follow liberalizations (Peter B. Henry 2000). Yet over the long run, diversification benefits may be small, provided a significant number of investors chase them.

Our data also reveal a puzzle. Why, if openness is so important for equity market correlations, did nineteenth-century stock markets move in different directions with such frequency? One possible reason is that economic fundamentals themselves were only slightly correlated during the nineteenth century; growth correlations in our sample were very low during the 1890-1913 period $(-0.002$ on average $)$, but are relatively high (0.42) in the contemporary period. Another possibility is that our data for the earliest period are particularly imperfect, and this may be partially responsible for the low correlations we document. To the extent that data limitations are not to blame, we surmise that differences in information technology and the rise of global asset managers are responsible.

\section{REFERENCES}

Agmon, Tamir, and Donald R. Lessard. 1977. "Investor Recognition of Corporate International Diversification." Journal of Finance, 32(4): 1049-55.

Bekaert, Geert, and Campbell R. Harvey. 2000. "Foreign Speculators and Emerging Equity Markets." Journal of Finance, 55(2): 565-613. Eichengreen, Barry. 2006. The European Economy since 1945: Coordinated Capitalism and Beyond. Princeton: Princeton University Press. Eichengreen, Barry, and Michael Bordo. 1997. "Implications of the Great Depression for the Development of the International Monetary System." In The Defining Moment: The Great Depression and the American Economy in the Twentieth Century, ed. Michael Bordo, Claudia Goldin, and Eugene White, 403-53. Chicago: University of Chicago Press. 
Eichengreen, Barry, and Hui Tong. 2003. "Stock Market Volatility and Monetary Policy: What the Historical Record Shows." In Reserve Bank of Australia 2003 Conference: Asset Prices and Monetary Policy, ed. Anthony Richards and Tim Robinson, 108-42. Sidney, AU: Reserve Bank of Australia.

Eun, Cheol S., and Sangdal Shim. 1989. "International Transmission of Stock Market Movements." Journal of Financial and Quantitative Analysis, 24(2): 241-56.

Global Financial Database. 2006. Global Financial Data. www.globalfinancialdata.com. (accessed May 19, 2006).

Goetzmann, William N., Lingfeng $\mathbf{L i}$, and $\mathrm{K}$. Geert Rouwenhorst. 2005. "Long-Term Global Market Correlations." Journal of Business, 78(1): 1-38.

Grubel, Herbert. 1968. "Internationally Diversified Portfolios: Welfare Gains and Capital Flows." American Economic Review, 58(5): 1299-1314.

Henry, Peter B. 2000. "Stock Market Liberalization, Economic Reform, and Emerging Market Equity Prices." Journal of Finance, 55(2): 529-64.

Hunter, Delroy. 2005. "What Drives Time Vari- ation in Emerging Market Segmentation?" Journal of Financial Research, 28(2): 261-80.

Keynes, John Maynard. 1920. The Economic Consequences of the Peace. New York: Harcourt, Brace and Howe.

Levy, Haim, and Marshall Sarnat. 1970. "International Diversification of Investment Portfolios." American Economic Review, 60(4): 668-75.

Morck, Randall, and Bernard Yeung. 1991. "Why Investors Value Multinationality." Journal of Business, 64(2): 165-87.

Obstfeld, Maurice, and Alan M. Taylor. "Global Capital Markets." In Globalization in Historical Perspective, ed. Michael D. Bordo, Alan M. Taylor and Jeffrey G. Williamson, 121-87. Chicago: University of Chicago Press.

Quinn, Dennis. 1997. "The Correlates of Change in International Financial Regulation." American Political Science Review, 91(3): 531-51.

Quinn, Dennis P. 2003. "Capital Account Liberalization and Financial Globalization, 18901999: A Synoptic View." International Journal of Finance and Economics, 8(3): 189-204.

Quinn, Dennis P., and Hans-Joachim Voth. 2007. "Free Flows, Limited Diversification: Explaining the Fall and Rise of Stock Market Correlations, 1890-2001." Unpublished. 